In cooperation with the U.S. Army, Camp Stanley Storage Activity

\title{
Induction Conductivity and Natural Gamma Logs Collected in 15 Wells at Camp Stanley Storage Activity, Bexar County, Texas
}

Data Series 132 
Blank Page 


\section{Induction Conductivity and Natural Gamma Logs Collected in 15 Wells at Camp Stanley Storage Activity, Bexar County, Texas}

By Gregory P. Stanton 


\section{U.S. Department of the Interior Gale A. Norton, Secretary}

\section{U.S. Geological Survey \\ P. Patrick Leahy, Acting Director}

\section{U.S. Geological Survey, Reston, Virginia: 2005}

For sale by U.S. Geological Survey, Information Services

Box 25286, Denver Federal Center

Denver, CO 80225

For more information about the USGS and its products:

Telephone: 1-888-ASK-USGS

World Wide Web: http://www.usgs.gov/

Any use of trade, product, or firm names in this publication is for descriptive purposes only and does not imply endorsement by the U.S. Government.

Although this report is in the public domain, permission must be secured from the individual copyright owners to reproduce any copyrighted materials contained within this report.

Suggested citation:

Stanton, G.P., 2005, Induction conductivity and natural gamma logs collected in 15 wells at Camp Stanley Storage Activity, Bexar County, Texas: U.S. Geological Survey Data Series 132, 29 p. 


\section{Contents}

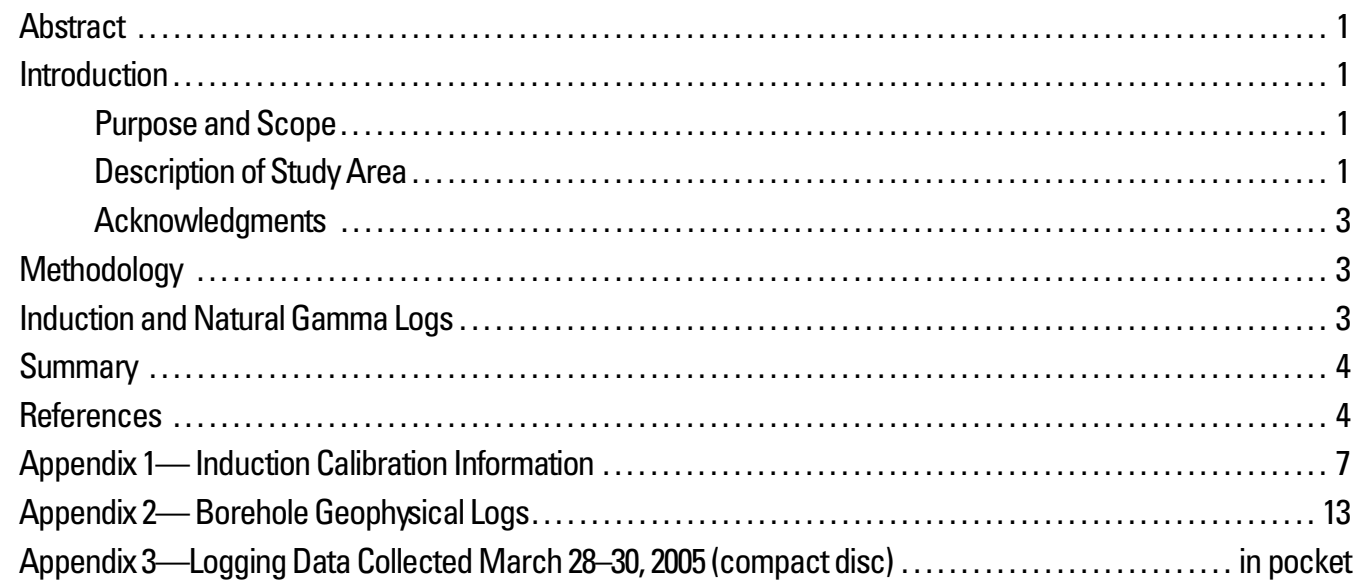

\section{Figure}

1. Map showing location of Camp Stanley Storage Activity and immediately adjacent area,

Bexar County, Texas, with locations of wells logged

\section{Table}

1. Well completion information for wells logged during March 28-30, 2005 ....

\section{Datums}

Vertical coordinate information is referenced to the National Geodetic Vertical Datum of 1929 (NGVD 29).

Horizontal coordinate information is referenced to the North American Datum of 1927 (NAD 27) and North American Datum of 1983 (NAD 83). 
Blank Page 


\title{
Induction Conductivity and Natural Gamma Logs Collected in 15 Wells at Camp Stanley Storage Activity, Bexar County, Texas
}

\author{
By Gregory P. Stanton
}

\section{Abstract}

The U.S. Geological Survey, in cooperation with the Camp Stanley Storage Activity conducted electromagnetic induction conductivity and natural gamma logging of 15 selected wells on the Camp Stanley Storage Activity, located in northern Bexar County, Texas, during March 28-30, 2005. In late 2004, a helicopter electromagnetic survey was flown of the Camp Stanley Storage Activity as part of a U.S. Geological Survey project to better define subsurface geologic units, the structure, and the catchment area of the Trinity aquifer. The electromagnetic induction conductivity and natural gamma log data in this report were collected to constrain the calculation of resistivity depth sections and to provide subsurface controls for interpretation of the helicopter electromagnetic data collected for the Camp Stanley Storage Activity.

Logs were recorded digitally while moving the probe in an upward direction to maintain proper depth control. Logging speed was no greater than 30 feet per minute. During logging, a repeat section of at least 100 feet was recorded to check repeatability of $\log$ responses.

Several of the wells logged were completed with polyvinyl chloride casing that can be penetrated by electromagnetic induction fields and allows conductivity measurement. However, some wells were constructed with steel centralizers and stainless steel screen that caused spikes on both conductivity and resulting resistivity log curves. These responses are easily recognizable and appear at regular intervals on several logs.

\section{Introduction}

The Camp Stanley Storage Activity (CSSA), located northwest of San Antonio, Texas (fig. 1), a separate activity of Red River Army Depot (near Texarkana, Texas), serves as a weapons and munitions supply, maintenance, test, and storage facility. The CSSA encompasses about 4,000 acres with
630,000 square feet of storage space. The facility supports locations throughout the contiguous United States and selected overseas areas.

The U.S. Geological Survey (USGS), in cooperation with the U.S. Army, CSSA, collected induction conductivity and natural gamma logs of 15 selected wells on the facility. The logs were collected to constrain the computation of resistivity depth sections and to provide subsurface controls for interpretation of a helicopter electromagnetic (HEM) survey flown of the CSSA in late 2004 (Smith and others, 2005). The objective of the USGS studies is to improve understanding of aquifer catchment area hydrogeology particularly in regard to environmental issues (Vanderglas and Murphy, 2004).

\section{Purpose and Scope}

The purpose of this report is to document electromagnetic (EM) induction conductivity and natural gamma log data collected in wells (table 1) during March 28-30, 2005, at various depths below land surface to calibrate the recently surveyed HEM data. CSSA identified 15 wells for EM induction-gamma logging that range from 84 to 465 feet total depth. The geophysical logging focused on the 15 wells listed in table 1. Logging parameters were limited to EM induction conductivity and natural gamma.

\section{Description of Study Area}

The CSSA is located in northern Bexar County, northwest of San Antonio (fig. 1) and overlies the Trinity aquifer. The Glen Rose Limestone, which comprises the upper zone and upper part of the middle zone of the Trinity aquifer, crops out at the CSSA (Clark, 2004). Clark (2004) describes the detailed geologic framework and hydrogeologic characteristics of the CSSA. Camp Bullis Training Site, a U.S. Army field training site, is on the northeastern, eastern, and southern boundaries of CSSA. 


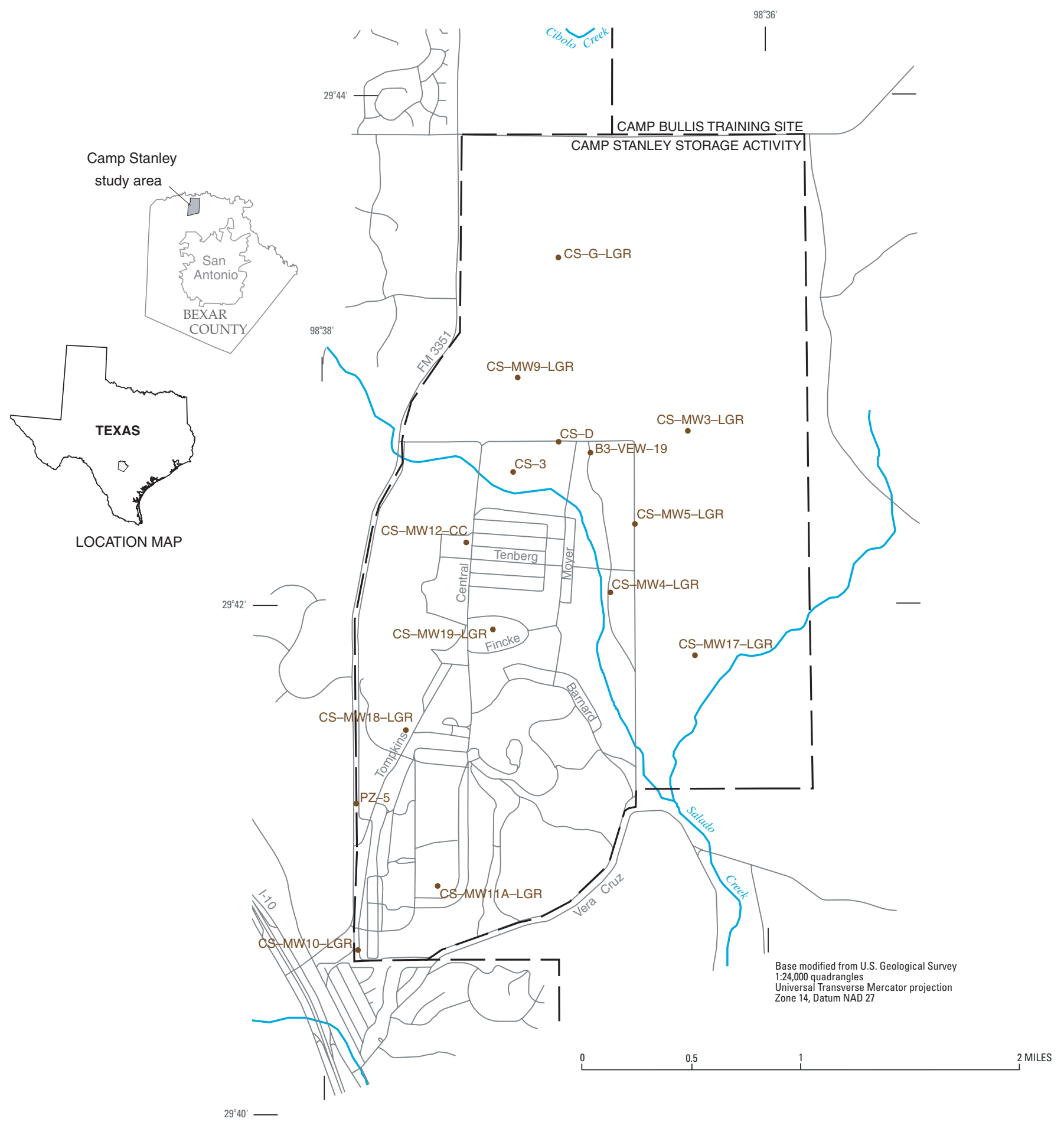

EXPLANATION

- ${ }^{\text {CS-3 MONITOR WELL AND NUMBER }}$

Figure 1. Map showing location of Camp Stanley Storage Activity and immediately adjacent area, Bexar County, Texas, with locations of wells logged. 


\section{Acknowledgments}

The author thanks Chris Beal and Samantha Elliot, CSSA Environmental Office contractors, for providing technical information on the wells and removing pumps prior to logging. The author also thanks Michael Nyman, USGS, for his assistance in the field during logging.

\section{Methodology}

Fifteen wells selected by the CSSA Environmental Office were logged using geophysical methods of EM induction and natural gamma (fig. 1, table 1). Pertinent information for wells such as well identifier, location, altitude, total depth, and casing/well construction record was provided by CSSA Environmental Office (table 1). The CSSA Environmental Office removed all downhole equipment such as pumps and cleared all obstructions from the borehole or casing prior to logging.

EM induction probes, which measure conductivity in airfilled or water-filled holes, perform well in open holes or polyvinyl chloride (PVC) cased holes. Conductivity measurement commonly is used to provide logs with both resistivity and conductivity curves (Keys, 1997) as shown by the logs in this report. The conductivity can be affected by the salinity of borehole and formation fluids and by the type of lithology encountered. Generally, pure carbonates, sands, and gravels have a lower conductivity (thus a higher resistivity) than clays or shales. All of the previous electrical logging of CSSA wells was done by resistivity logging methods (Keys, 1997), which is the most commonly used electrical logging method for EdwardsTrinity aquifer studies at the CSSA (Chris Beal, Camp Stanley Storage Activity, oral commun., 2004). Resistivity logging requires an uncased and water-filled drill hole (Keys, 1997). Consequently there is little information from the shallow part of the hydrogeologic section above the water table, which is critical in interpretation of the HEM method that has a penetration depth on the order of about 15 to 30 feet in this geoelectrical setting (Smith and others, 2005).

A Geonics EM39 induction conductivity probe was used on all wells and interfaced to surface instrumentation in the logging truck through a 0.25 -inch-diameter, four-conductor wireline and a Mount Sopris MGXII log acquisition system. The EM39 was calibrated twice daily using manufacturer's recommended procedures (Geonics Limited, 1992) at temperatures within the range expected in the boreholes. To attain a stable temperature, the probe was hung in a well for 20 to 30 minutes prior to calibration. During a two-point calibration process, the probe was calibrated to a (1) zero conductivity environment, and (2) calibration coil of known conductivity with the bottom of the probe at least 9 feet above the ground. The calibration also was checked periodically between calibrations (appendix 1).

Natural gamma logs provide a record of gamma radiation detected at depth in a borehole. Fine-grained sediments that contain abundant clay tend to be more radioactive than quartzgrain sandstones or carbonates (Keys, 1997). The natural gamma probe was run in tandem above the EM induction probe and was recorded in natural gamma counts per second simultaneously as the induction log was recorded. A Mount Sopris 2PGA-1000 natural gamma probe with a sodium iodide detector was used. The natural gamma probe is calibrated at the factory and does not require calibration in the field. The natural gamma and induction logs (appendix 2) collectively can be very useful in determining lithologies and contact depths of the strata penetrated in the borehole.

The EM induction conductivity measurements (commonly sensitive to metallic conductive objects) were affected at depths corresponding with metal objects such as centralizers and stainless steel screens in several of the logged wells or in wells with steel casing from the surface to the open part of the borehole. Likewise, natural gamma count rates, which commonly increase in the proximity of clay and shale, could increase slightly adjacent to any bentonite seals in the wells. Some wells contained steel casing that extended from the surface to the open interval of the well. In this case, induction logs were only recorded in the open borehole section.

Logs were recorded digitally while moving the probe in an upward direction; this removed all slack from the wireline and aided in maintaining proper depth control. All log depths are referenced to land surface datum altitude (table 1). Logging speed was no greater than 30 feet per minute. During logging, a repeat section of at least 100 feet was recorded to check repeatability of $\log$ responses. Digital data are in appendix 3 on the enclosed compact disc and are available for download with this report.

Because all of these wells are used for ground-waterquality sampling and some contain contaminated ground water, the logging equipment that was lowered into the wells was decontaminated. This decontamination procedure occurred prior to equipment mobilization to CSSA and upon probe removal from wells that contained contamination.

\section{Induction and Natural Gamma Logs}

The 15 wells were logged during March 28-30, 2005, by USGS personnel with assistance from contractors of the CSSA Environmental Office. Well information listed in table 1 was provided by the CSSA Environmental Office for the 15 wells. The logs are included in Appendix 2 of this report.

Several of the logged wells were completed with PVC casing that can be penetrated by the EM induction fields and allows conductivity measurement of the formation and associated fluids. However some wells were constructed with steel centralizers in the annulus between the borehole wall and the PVC casing and with stainless steel screen sections at the bottom of the well. These metal objects perturb the electromagnetic fields and cause numerous spikes on both conductivity and resulting resistivity log curves. These responses are easily recognizable 


\section{Induction Conductivity and Natural Gamma Logs, Camp Stanley Storage Activity, Bexar County, Texas}

and appear at regular intervals on logs collected in the following wells: CS-MW3-LGR, CS-MW4-LGR, CS-MW5-LGR, CS-MW9-LGR, CS-MW10-LGR, CS-MW11A-LGR, CSMW12-CC, CS-MW17-LGR, CS-MW18-LGR, CS-MW19LGR, and PZ-5. All other log measurement data are considered to be of good quality. Other wells, such as CS-3, CS-D, and CS-G-LGR, have steel casing from surface to a certain depth; in this case, the resistivity and conductivity curves were not recorded in the steel-cased intervals. Because the wells were logged in an upward direction, the logging wireline was not pulled to full tension until the probe was lifted from the bottom; thus no probe movement occurred until full tension was regained. For this reason, when using the logs or generated computer files, it is generally advisable to not use the first 2 feet of the log curves or values in the computer files.

All logs collected were recorded digitally and archived in the Log ASCII Standard (LAS) version 2 format, which is the industry standard for borehole geophysical data storage. The digital data are in appendix 3 on the enclosed compact disc and available for download. The LAS file format has been developed and promoted by the Canadian Well Logging Society (2005). The LAS files contain several lines of header data followed by columns of borehole geophysical data with depth at an interval of 0.162 foot. Geophysical data values of -999.250 for any parameter in the LAS file represent null values for that parameter.

\section{Summary}

The U.S. Geological Survey (USGS), in cooperation with the U.S. Army, Camp Stanley Storage Activity (CSSA), conducted EM induction conductivity and natural gamma logging of 15 selected wells on the CSSA during March 28-30, 2005. The CSSA is located in northern Bexar County, Texas, northwest of San Antonio and overlies the Trinity aquifer. In late 2004, an HEM survey of the CSSA was flown as part of a USGS project to better define subsurface geologic units, structure, and catchment area of the Trinity aquifer. The EM induction and natural gamma log data were collected to refine the calibration and provide subsurface controls for interpretation of the HEM data.

EM induction conductivity and resistivity log responses can be affected by the salinity of borehole and formation fluids and by the type of lithology encountered. Generally, pure carbonates, sands, and gravels have a lower conductivity (thus a higher resistivity) than clays or shales. Similarly, natural gamma logs provide a record of gamma radiation detected at depth in a borehole. Fine-grained sediments that contain abundant clay tend to be more radioactive than quartz-grain sandstones or carbonates. These logs, when run in tandem, can be very useful in determining lithologies and contact depths of strata penetrated in the borehole.

Logs were recorded digitally while moving the probe in an upward direction to maintain proper depth control. Logging speed was no greater than 30 feet per minute. During logging, a repeat section of at least 100 feet was recorded to check repeatability of $\log$ responses.

Several of the wells logged were completed with PVC casing that can be penetrated by the EM induction fields and allows conductivity measurement; however, some wells were constructed with steel centralizers and stainless steel screen, which caused spikes on both conductivity and resulting resistivity log curves. These responses are easily recognizable and appear at regular intervals in several logs. Otherwise all log measurement data are considered to be of good quality.

\section{References}

Canadian Well Logging Society, 2005, LAS information-Log ASCII Standard (LAS) software: accessed April 4, 2005, at http://www.cwls.org/las_info.php

Clark, A.K., 2004, Geologic framework and hydrogeologic characteristics of the Glen Rose Limestone, Camp Stanley Storage Activity, Bexar County, Texas: U.S. Geological Survey Scientific Investigations Map 2381, 1 sheet.

Geonics Limited, 1992, Geonics EM39 borehole conductivity logger operating manual: Mississauga, Ontario, Canada, Geonics Limited.

Keys, W. S., 1997, A practical guide to borehole geophysics in environmental investigations: Boca Raton, Fla., CRC Press, $176 \mathrm{p}$.

Smith, B.D., Cain, M.J., Clark, A.K., Moore, D.W., Faith, J.R., and Hill, P., 2005, Helicopter electromagnetic and magnetic survey data and maps, northern Bexar County, Texas: U.S. Geological Survey Open-File Report 2005-1158, $123 \mathrm{p}$.

Vanderglas, Brian, and Murphy, Brian, 2004, An integrated approach to contaminant mass removal from vadose and saturated fractured bedrock, in 2004 Fractured Rock Conference-State of the Science and Measuring Success in Remediation, Portland, Maine, Sept. 13-15, 2004: National Ground Water Association, p. 310-315. 
Table 1. Well completion information for wells logged during March 28-30, 2005 (Chris Beal, Camp Stanley Storage Activity, written commun., 2005).

[CSSA, Camp Stanley Storage Activity; USGS, U.S. Geological Survey; LSD, land surface datum; PVC, polyvinyl chloride; --, not applicable; SS, stainless steel; OH, open hole]

\begin{tabular}{|c|c|c|c|c|c|c|c|c|c|c|c|c|c|}
\hline $\begin{array}{l}\text { CSSA } \\
\text { well ID }\end{array}$ & $\begin{array}{l}\text { USGS } \\
\text { site ID }\end{array}$ & $\begin{array}{l}\text { Latitude } \\
\text { NAD } 1983 \\
\text { (degrees, } \\
\text { minutes, } \\
\text { seconds) }\end{array}$ & $\begin{array}{c}\text { Longitude } \\
\text { NAD } 1983 \\
\text { (degrees, } \\
\text { minutes, } \\
\text { seconds) }\end{array}$ & $\begin{array}{l}\text { Altitude } \\
\text { of LSD } \\
\text { (feet } \\
\text { above } \\
\text { NGVD 29) }\end{array}$ & $\begin{array}{l}\text { Top of } \\
\text { casing } \\
\text { (feet } \\
\text { above } \\
\text { NGVD 29) }\end{array}$ & $\begin{array}{c}\text { Cored } \\
\text { depth } \\
\text { (feet } \\
\text { below } \\
\text { LSD) }\end{array}$ & $\begin{array}{l}\text { Final } \\
\text { reamed/ } \\
\text { drilled } \\
\text { depth } \\
\text { (feet } \\
\text { below } \\
\text { LSD) }\end{array}$ & $\begin{array}{c}\text { Steel } \\
\text { casing } \\
\text { diameter } \\
\text { (inches) } \\
\text { and depth } \\
\text { (feet below } \\
\text { LSD) }\end{array}$ & $\begin{array}{l}\text { PVC riser } \\
\text { diameter } \\
\text { (inches) } \\
\text { and depth } \\
\text { (feet } \\
\text { below } \\
\text { LSD) }\end{array}$ & $\begin{array}{l}\text { Annular } \\
\text { grout } \\
\text { seal } \\
\text { interval } \\
\text { (feet } \\
\text { below } \\
\text { LSD) }\end{array}$ & $\begin{array}{l}\text { Bentonite } \\
\text { seal } \\
\text { interval } \\
\text { (feet } \\
\text { below } \\
\text { LSD) }\end{array}$ & $\begin{array}{c}\text { Sand } \\
\text { pack } \\
\text { interval } \\
\text { (feet } \\
\text { below } \\
\text { LSD) }\end{array}$ & $\begin{array}{l}\text { Opening } \\
\text { interval } \\
\text { (feet } \\
\text { below } \\
\text { LSD) } \\
\text { and type }\end{array}$ \\
\hline CS-MW3-LGR & 294241098362301 & 294241.2 & 983623.1 & $1,329.43$ & $1,332.45$ & 438.5 & 428 & -- & $4.0 / 402$ & -- & $\begin{array}{l}395-400 \\
428-438.5\end{array}$ & $400-428$ & 402-427 SS \\
\hline CS-MW4- LGR & 294203098364401 & 294202.8 & 983643.9 & $1,205.30$ & $1,207.84$ & 336.5 & 325 & -- & $4.0 / 299$ & -- & $\begin{array}{l}291.5-296.5 \\
325-336.5\end{array}$ & $296.5-325$ & 299-324 SS \\
\hline CS-MW5-LGR & 294220098363701 & 294219.8 & 983637.1 & $1,335.47$ & $1,338.51$ & 462 & 446 & -- & $4.0 / 420$ & -- & $\begin{array}{l}413-417 \\
446-462\end{array}$ & $417-446$ & $420-445 \mathrm{SS}$ \\
\hline CS-MW9-LGR & 294254098371001 & 294254.1 & 983710.4 & $1,252.76$ & $1,255.58$ & 323 & 322 & -- & $4.0 / 296$ & -- & $\begin{array}{l}289-294 \\
322-323\end{array}$ & $294-322$ & 296-321 SS \\
\hline CS-MW10-LGR & 294042098375301 & 294042.1 & 983752.6 & $1,184.97$ & $1,187.68$ & 405 & 396 & -- & $4.0 / 370$ & -- & $\begin{array}{l}363-368 \\
396-405\end{array}$ & $368-396$ & 370-395 SS \\
\hline CS-MW11A-LGR & 294048098373101 & 294048.0 & 983730.7 & $1,201.24$ & $1,204.03$ & 494 & 445 & -- & $4.0 / 420$ & $0-413$ & $413-418$ & $418-445.5$ & 420-445 SS \\
\hline CS-MW12-CC & 294214098372401 & 294214.4 & 983723.5 & $1,254.73$ & $1,257.31$ & 502 & 465 & -- & $4.0 / 440$ & $0-432.5$ & $\begin{array}{l}432.5-437.5 \\
465.5-502\end{array}$ & $437.5-465.5$ & 440-465 SS \\
\hline CS-MW17-LGR & 294150098361901 & 294150.1 & 983619.2 & $1,254.01$ & $1,257.01$ & 401 & 392 & -- & $4.0 / 367$ & $0-359$ & $\begin{array}{l}359-364 \\
392-401\end{array}$ & $364-392.5$ & 367-392 SS \\
\hline CS-MW18-LGR & 294130098373901 & 294129.6 & 983739.2 & $1,280.62$ & $1,283.61$ & 422 & 411 & -- & $4.0 / 385$ & $0-378$ & $378-383$ & $383-411$ & 385-410 SS \\
\hline CS-MW19-LGR & 294154098371601 & 294154.4 & 983715.9 & $1,252.71$ & $1,255.53$ & 382 & 365 & -- & $4.0 / 340$ & $0-331$ & $\begin{array}{l}331-336 \\
365-382\end{array}$ & $336-365$ & 340-365 SS \\
\hline CS-G-LGR & 294322098365801 & 294322.1 & 983657.8 & $1,324.80$ & $1,325.47$ & 339.5 & 339 & $5.5 / 183$ & -- & $0-155$ & -- & -- & $183-339 \mathrm{OH}$ \\
\hline CS-3 & 294231098371201 & 294230.9 & 933711.9 & $1,236.87$ & $1,240.17$ & -- & 314 & $6.0 / 205$ & -- & $0-205$ & -- & -- & $205-314 \mathrm{OH}$ \\
\hline CS-D & 294240098365801 & 294239.9 & 983657.6 & $1,233.31$ & $1,236.03$ & -- & 263 & & -- & $0-205$ & -- & -- & $205-263 \mathrm{OH}$ \\
\hline PZ-5 & 294055098375501 & 294055.2 & 983755.2 & $1,208.86$ & $1,210.97$ & -- & 125 & -- & $4.0 / 85$ & -- & -- & -- & 85-125 PVC \\
\hline B3-VEW-19 & 294236098365001 & 294235.7 & 983649.5 & $\begin{array}{l}1,242 \\
\text { (estimated) }\end{array}$ & $\begin{array}{l}1,242 \\
\text { (estimated) }\end{array}$ & 284 & 84 & -- & $2.0 / 34$ & -- & -- & -- & 34-84 PVC \\
\hline
\end{tabular}

